\title{
Effect of Work Team, School Culture on Decision Making of The Principals of The State High School in Jakarta
}

\author{
Venny Oktaviany ${ }^{1, a^{*}}$, Mukhneri Mukhtar ${ }^{2, b}$ and Mochamad Wahyudi ${ }^{3, c}$ \\ ${ }_{1}^{1}$ Doctorate Programme of Management Education, Universitas Negeri Jakarta, Jl. Rawamangun Muka, Jakarta Timur, 13220, Indonesia \\ 2 Department of Management Education, Universitas Negeri Jakarta, Jl. Rawamangun Muka, Jakarta Timur, 13220, Indonesia \\ ${ }^{3}$ Department of Accounting Management System, Universitas Bina Sarana Informatika, Jl. Kamal Raya No. 18, Ring Road Barat, Cengkareng, Jakarta Barat, 11730, Indonesia \\ a vennyoktaviany_mp15s3@mahasiswa.unj.ac.id; b mukhneri@unj.ac.id; c wahyudi@bsi.ac.id \\ ${ }^{*}$ Corresponding Author
}

How to Cite: Oktaviany, V., Mukhtar, M., Wahyudi, M.(2019). Effect of Work Team, School Culture on Decision Making of The Principals of The State High School in Jakarta. International Journal for Educational and Vocational Studies, 1(4), 294-298

\section{ARTICLE HISTORY}

Received: 18 June 2019

Revised: 20 July2019

Accepted: 5 August 2019

KEYWORDS

Work Teams;

School Culture;

Decision Making;

\section{ABSTRACT}

The objective of this study is to learn the influence of work team and school culture toward decision making of high school in Jakarta. This study was the quantitative approach, and path analysis method was applied to analyze the data. In this study, principals of state high school have been chosen as a unit analysis and 91 samples of state high school in Jakarta. The results of this study showed that: (1) work teams have a direct positive effect on decision making; (2) school culture has a direct positive effect on decision making. At last, this study suggested that work teams and school culture were important determinants of the principal's decision making.

This is an open access article under the CC-BY-SA license.

\section{INTRODUCTION}

Decision making is one of the most important activities that occur every day which includes the school administrators such as the principals and the people who have a significant effect on the school operations, so that the principals is the decision maker. Decisions are made at all levels of the school organization relating to decisions about state school goals and strategies.

A decision making on the issue of organization is very important because it can affect a person's behavior in the organization, so that it directly or indirectly will be able to influence the team work and decision making is habituation which eventually becomes a value of the own culture. This is based on Lunenburg's opinion (2010) as follows, decision making is one of the most important activities in which school administrators engage daily.... Because decision making is so important and can have such significant effects on the operation of schools, it has been suggested that administration is decision making.

In addition, the effective work team needs cooperation to collective responsibility in completing its responsiblities, so that the effective work team has the confidence and optimistic toward the success achieved. So, it can be said that the work team that has achieved success will increase the confidence of team members about future successes and they will be motivated to work harder in the turn. This is as stated by Manzoor, et al., (2011) that, work team is an important factor for smooth functioning of an organization. Most of the organizational activities become complex due to advancement in technology therefore teamwork is a major focus of many organizations.

Related to the school improvement, a school culture is also one of the most neglected, even though according to Azizollah et al., (2016) organizational culture and organizational commitment are special concepts in management.

School culture is one of the complex and important concepts in education because it is the heart of school culture, and becomes difficult to understand and change. This was stated by Stoll quoted from Schein (2000) as follows, Schein considers the basic essence of an organisation's culture to be, the deeper level of basic assumptions and beliefs that are shared by members of an organisation, that operate unconsciously, and that define in a basic 'taken-for-granted' fashion an organisation's view of itself and its environment. 


\section{RELATED WORK}

\subsection{Decision Making}

A decision making is a process of deciding rational and consistent alternatives and maximizing value within certain limits.

In decisions making, each individual thinks and makes judgments before acting, so they need to understand of how individuals make decisions that can be useful in explaining and predicting their behavior. This is as explained by Schermerhorn (2010), decision making is the process of making choices among alternative possible courses of action.

Anderson (2012) gives the concept as follows, decision making is the term is generally associated with the first five steps of problem solving process, such as: (1) defining the problem, (2) identifying alternatives, (3) determining criteria, (4) evaluating alternatives, (5) choosing one alternative.

Furthermore Eisenfuhr quoted by Lunenburg (2010) explains that decision making has 3 (three) elements as follows, Decision making is a process of making a choice from a number of alternatives to achieve a desired result. This definition has three key elements. First, decision making involves making a choice from a number of options. Second, decision making is a process that involves more than simply a final choice from among alternatives. Finally, the "desired result" mentioned in the definition involves a purpose or target resulting from the mental activity that the decision maker engages in to reach a final decision.

Noorale (2012) concludes that the journals relating to decision making are as follows: (a) Decision-making is one of the most important functions of the managerial job thus, the primary duty of managers is decision making; (b) In terms of the decision-making process I noted that there are numerous approaches to decision-making. In spite of general similarities among them, there are some real differences that result in a lack of conceptual consensus; (c) The most important models of decision-making are defined as (1) The rational or classical model, which is based on quantitative disciplines, (2) The organizational model, which is based on both behavioral and quantitative analysis, and (3) The political model, which is almost totally behavioral.

\subsection{Work Team}

At present in the modern organizational concept, the ability to work in a team is one of the absolute requirements that must be owned, because compactness is considered more important than the ability to work separately. It means that a job is carried out by those who have different competencies. Every difference is measured based on science and experience and measurements are measured based on the results of the test and also monitoring as long as the person is working in the organization. The concept of the right man and the right place is considered as the most representative concept today to be able to realize the formation of competent work teams.

Generally, teams are formed for different purposes, so, the challenges they pose are different. However, a work team consisting of people group are who have the same vision and mission who work in an effort to realize the determined work that is done daily in an organization, as explained by Griffin and Moorhead (2014), work teams, teams that do the daily work of an organization. The establishment of team work is done because of the desire to speed up a job to be carried out depends on the time and targeted results. A team work from that perspective, generates positive synergy at work through coordination of effort. The individual efforts result in a level of performance that is more than the sum of those individual inputs. (Zayed and Kamel, 2005).

From the various opinions of experts in interpreting the work team of each person gives different meanings based on their point of view and interests. This is as said by Chandler, et al., (2009) that, work teams, continuing work units responsible for producting goods or providing services. According to Kozlowski dan Bell Work teams can be defined as groups that exist for performing organizationally relevant tasks, that maintain a certain degree of interdependence in terms of goals and tasks, that manage and maintain their boundaries, and that are immersed in an organizational context which limits their activity and influences the extent of their interchange with other teams within the organization (Rico, and Hera, 2011).

\section{METHODS}

This study used a quantitative approach through survey methods with causal techniques. Hypothesis testing is carried out using path analysis techniques with constellation models between variables, consisting of 3 variables; exogenous variables of work team $\left(\mathrm{X}_{1}\right)$, school culture $\left(\mathrm{X}_{2}\right)$, and endogenous variables; decision making (Y).

The proposed hypothesis will be drawn into conclusions through calculation of the path coefficient and significance for each pathway studied. Based on these path analysis tests, each test of the statistical hypothesis tested is a positive direct effect.

First hypothesis: testing the direct influence of the work team $\left(\mathrm{X}_{1}\right)$ towards decision making $(\mathrm{Y})$.

$$
\begin{aligned}
& \mathrm{H}_{0}: \beta_{1} \leq 0 \\
& \mathrm{H}_{1}: \beta_{1}>0
\end{aligned}
$$

Second hypothesis: testing the direct influence of school culture $\left(\mathrm{X}_{2}\right)$ towards decision making $(\mathrm{Y})$.

$$
\begin{aligned}
& \mathrm{H}_{0}: \beta_{2} \leq 0 \\
& \mathrm{H}_{1}: \beta_{2}>0
\end{aligned}
$$

Notes:
$\mathrm{H}_{0}$ : zero hypothesis
$\mathrm{H}_{1}$ : one hypothesis or alternative hypothesis 
$\beta_{\mathrm{y} 1}$ : path coefficients in the population that show the direct influence of the team work (X1) on decision making $(\mathrm{Y})$.

$\beta_{\mathrm{y} 2}$ : path coefficients in the population that show the direct influence of the school culture (X2) on decision making $(\mathrm{Y})$.

\section{RESULTS AND DISCUSSION}

Based on the result of the path analysis calculation among variables that were found in general, there was an influence of exogenous variables on endogenous variables. Meanwhile the hypothesis testing showed that the hypothesis proposed in this study generally proven the path had positively affected.

Normality testing uses the Liliefors formula. The hypothesis presented in the normality test is:

$\mathrm{H}_{0}$ : Error data comes from populations with normal distribution, if the value of $\mathrm{L}_{\text {count }} \leq \mathrm{L}_{\text {table }}(\alpha=0,05)$, and $\mathrm{n}=91$.

$\mathrm{H}_{1}$ : Error data comes from the population is not normally distributed, if the value of $\mathrm{L}_{\text {count }} \geq \mathrm{L}_{\text {table }}$ $(a=0,05)$, and $n=91$.

The summary of the calculation results for the estimated error normality test is presented in the following table:

Table 1. Summary of Normality Test Results

\begin{tabular}{ccccccc}
\hline \multirow{N}{*}{$\mathrm{N}$} & Estimated & & & \multicolumn{2}{c}{ Ltable } & \\
\cline { 5 - 6 } 0 & Error & $\mathrm{n}$ & $\mathrm{L}_{\text {count }}$ & $\mathrm{a}=$ & $\mathrm{a}=$ & Summary \\
& Regression & & & $5 \%$ & $1 \%$ & \\
\hline \multirow{2}{*}{1} & $\mathrm{Y}_{\text {on } \mathrm{X}_{1}}$ & 91 & 0,065 & 0,092 & 0,108 & Distributes \\
& & & 1 & 9 & & normally \\
\hline \multirow{2}{*}{2} & Y on $\mathrm{X}_{2}$ & 91 & 0,087 & 0,092 & 0,108 & Distributes \\
& & & 9 & 9 & & normally \\
\hline
\end{tabular}

The next step is having the correlational analysis by reviewing the level and significance of the relationship between pairs of exogenous variables and endogenous variables. The overall results of the significance test and regression linearity are summarized in the following table 2 .

Table 2. Summary of Test Results for significance and linearity of Regression

\begin{tabular}{ccccc}
\hline Reg & Equation & $\begin{array}{c}\text { Regression } \\
\text { Test }\end{array}$ & Linearity Test & Summary \\
\hline
\end{tabular}

\begin{tabular}{|c|c|c|c|c|c|c|c|}
\hline & & & \multirow[b]{2}{*}{ Lcount } & $F_{\text {tabel }}$ & \multirow[b]{2}{*}{$\mathrm{L}_{\text {count }}$} & \multirow{2}{*}{$\begin{array}{c}F_{\text {tabel }} \\
\alpha=0,05\end{array}$} & \\
\hline & & & & $\begin{array}{c}\alpha= \\
0,01\end{array}$ & & & \\
\hline$Y$ atas $X_{1}$ & $\begin{array}{l}\widehat{\mathbf{X}}_{3} \\
80,75 \\
0,428 X_{1}\end{array}$ & + & 22,56 & $\begin{array}{r}6,93^{*} \\
*\end{array}$ & 0,934 & $1,70^{\mathrm{ns}}$ & $\begin{array}{l}\text { The regression } \\
\text { is very } \\
\text { significant/ } \\
\text { Regression is } \\
\text { linear }\end{array}$ \\
\hline$Y$ atas $X_{2}$ & $\begin{array}{l}\widehat{\mathbf{X}}_{3} \\
97,77 \\
0,346 \mathrm{X}_{2}\end{array}$ & + & 17,94 & $\begin{array}{r}6,93^{*} \\
*\end{array}$ & 0,687 & $1,65 \mathrm{~ns}$ & $\begin{array}{l}\text { The regression } \\
\text { is very } \\
\text { significant/ } \\
\text { Regression is } \\
\text { linear }\end{array}$ \\
\hline
\end{tabular}

Notes:

** : Very Significant

ns : Non significant (regression is linear)

One of the important requirement which must be completed is the existence of a significant correlation between related variables. The correlation between variables is calculated by the correlation coefficient.

The magnitude of the direct effect and significance test of each path (Path Analysis) are summarized in the following table:

Table 3. Summary of Path Significance Test Results

\begin{tabular}{|c|c|c|c|c|c|c|}
\hline \multirow{2}{*}{ No. } & Effect & Coefficie & & & \multicolumn{2}{|c|}{$F_{\text {tabel }}$} \\
\hline & Direct & Path & & & $\alpha=0,05$ & $\begin{array}{l}a= \\
0,01\end{array}$ \\
\hline 1 & $Y$ toward $X_{3}$ & 0,337 & 88 & 3,34 & 1,99 & 2,63 \\
\hline 2 & $Y$ toward $X_{3}$ & 0,268 & 88 & 2,66 & 1,99 & 2,63 \\
\hline
\end{tabular}

Structurally, the overall diagram of the path of each structure can be seen in the following figure: 


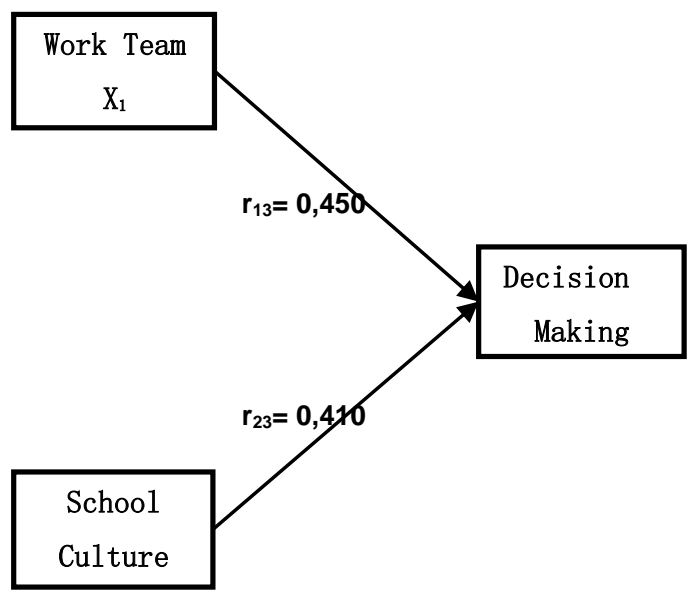

Figure 1. Causal Path Diagram of influence of $X_{1}$ and $X_{2}$ toward Y

After analyzing the structure model, the next calculation results obtained are used to test the hypothesis. The hypothesis proposed will be drawn conclusions by calculating the path coefficient value and significance for each path studied.

The summary of the two hypotheses can be seen in the following table:

Table 4. Summary of Hypothesis Testing Results

\begin{tabular}{|c|c|c|c|c|}
\hline $\begin{array}{l}\text { Direct } \\
\text { Effect }\end{array}$ & $\begin{array}{c}\text { Path } \\
\text { Coefficient }\end{array}$ & $T_{\text {count }}$ & $F_{\text {table }}$ & Test Result \\
\hline$X_{1}$ of $Y$ & 0,337 & 3,34 & 1,99 & $\begin{array}{l}\mathrm{H}_{0} \text { is refused, } \mathrm{H}_{1} \text { is } \\
\text { accepted. Consists of the } \\
\text { direct positive influence of } X \\
\text { toward } \mathrm{X}_{3}\end{array}$ \\
\hline$X_{2}$ of $Y$ & 0,268 & 2,66 & 1,99 & $\begin{array}{l}\mathrm{H}_{0} \text { is refused, } \mathrm{H}_{1} \text { is } \\
\text { accepted. Consists of the } \\
\text { direct positive influence of } \mathrm{X}_{2} \\
\text { toward } \mathrm{X}_{3}\end{array}$ \\
\hline
\end{tabular}

\section{Discussion}

Based on the result of the analysis and hypothesis testing, it can be concluded that in general it is proven that each path tested has a direct positive effect. Then based on the conclusions of this study, the decision making of State High Schools in DKI Jakarta can be increased by strengthening the work team, creating a conducive school culture.

First hypothesis testing showed that there was a significant positive relationship between work team and decision making shown by tcount $=4.75$ greater than ttable $=1.99$ at the significant level $\alpha=0.05$. It was obvious because based on the opinion of Schermerhorn (2010), decision making is the process of making choices among alternative possible courses of action. It is one of the most important group process. But it also complicated by the fact that teams can make decision in different ways and face special decision-making challenges. In addition, according to Ingram work team is a strategy that has a potential to improve the performance of individuals and organizations, but it needs to be nurtured over time. Organizations need to look at strategies for improving performance in the light of increasingly competitive environments. Top managers need to have the vision to introduce work team activities within the organizations, the sensitivity to nourish it and the courage to permit teams to play an important part in decision making. (Manzoor et, al.,2011).

Second hypothesis testing showed that there was a significant positive relationship between school culture and decision making as shown by tcount $=4.24$ greater than ttable $=1.99$ at a significant level $\alpha=0.05$. In line with Sudaryono (2014), the results of this study was in accordance with several rational models in decision making that did not recognize cultural differences, but it must be admitted that the background of the cultural values believed by decision makers can significantly influence the selection of problems, the depth of analysis, the interests given to logic and rationality, or whether organizational decisions must be made autocratically. Furthermore that multiple environment factors support the primary input of organizational structure, and that decision making at the individual and group/team level is an important process to support organizational design and effectiveness. Support organizational process include HR policies and culture, socialization, and mentoring. (Kinicki and Fugate, 2016).

\section{CONCLUSION}

Based on the results of the analysis and discussion of this study, it can be concluded that the work team and school culture have a positive direct effect on decision making toward the principals of the State High Schools in DKI Jakarta. It means that the stronger the work team and school culture that is strongly perceived, it can improve the accuracy of the decision making of the principals of State High Schools in DKI Jakarta. So, based on the conclusions of the results, decision making of The State High Schools in DKI Jakarta can be improved by strengthening the work team, creating a conducive school culture, and making the right decisions.

\section{Acknowledgment.}

The gratitude and appreciation are given to all those who have helped this research.

\section{REFERENCES}

Azizollah Arbabisarjou, Farhang Abolghasem, and Dadgar Mohammad Amin. (2016). The Relationship Between Organizational Culture and Organizational Commitment in Zahedan University of 
Medical Sciences, Global Journal of Health Science: Published 2016 Jul; 8(7).

Carl D Clickman, Stephen P Gordon, Jovita M Ross-Gordon. (2010). Supervision and Instructional Leadership: A Development Approach (Boston: Pearson Education Inc.)

Chandler, Dawn, Coget, James B. Lau. (2009). Behavior in Organizations: An Experiential Approach, New York: McGraw-Hill.

Cleveland Roger et al. (2012). School Culture, Equity, and Student Academic Performance in a Rural Applachian School, Kentucky Journal of Excellence in College Teaching and Learning, Vol. 9, Article 4.

David R Anderson. (2012). An Introduction to Management Science: Quantitative Approaches to Decision Making (USA: South-Western Cengage Learning)

Fred C Lunenburg. (2010). The Decision Making Process (National Forum of Educational Administration and Supervision Journal) Vol 27 Number 4 pp 1-12

John R Schermerhorn Jr. (2010). Introduction to Management (Asia: John Wiley \& Sons Pte Ltd)

Kent D Peterson and Terrence D Deal. (2009). How Leaders Influence the Culture of Schools (San Francisco: Jossey-Bass Publishers)

Kinicki, Angelo, Mel Fugate. (2016). Organization Behavior: Practical, Problem-Solving Approach (Singapore: McGraw-Hill Education)

Louise Stoll. (2000). School Culture Department of Education (University of Bath) Reprinted from School Improvement Network's Bulletin No 9 Autumn 1998 Institute of Education, (University of London) pp 9-14

Manzoor Sheikh Raheel et al. (2011). Effect of Teamwork on Employee Performance, International Journal of Learning \& Development, Vol. 1, No. 1, ISSN 2164-4063.

Noorale Mahmood. (2012). Factors Influencing Strategic Decision-Making, HRMars: International Journal of Academic Research in Business and Social Sciences, Vol. 2, No. 7 ISSN: 2222-6990, July.

Ramón Rico, Carlos María Alcover de la Hera and Carmen Tabernero. (2011). Work Team Effectivenes, A Review of Research from The Last Decade (1999-2009) (Psychology in Spain) Vol 15 No 1 pp 57-79

Ricky W Griffin and Gregory Moorhead. (2014). Organizational Behavior; Managing People and Organizations (Canada: Cengage Learning)

Roby, Douglas E. 2014 Teacher Leader Impacting School Culture, Wright State University: Education Vol. 131, No. 4.

Sheikh Raheel Manzoor et al. (2011). Effect of Teamwork on Employee Performance (International Journal of Learning \& Development) Vol 1 No 1 ISSN 2164-4063 pp 110-126

Sudaryono. (2014). Budaya dan Perilaku Organisasi (Jakarta: Lentera Ilmu Cendekia)

Zayed Adel Mohamed, Mostafa Mostafa Kamel. (2005). Teams and Work Group, Cairo: Center for Advancement of Postgraduate Studies and Research in
Engineering Sciences, Faculty of Engineering - Cairo University (CAPSCU). 